\title{
Identity And Creativity In Parang Sukawati Batik
}

\author{
Nanang Rizali ${ }^{1}$, Bani Sudardi ${ }^{2}$ \\ \{nanangkriya@yahoo.co.id ${ }^{1}$, banisudardi@yahoo.co.id ${ }^{2}$ \} \\ ${ }^{1}$ Fakultas Seni Rupa dan Desain, Universitas Sebelas Maret, Jl. Ir. Sutami 36 A Surakarta, \\ Indonesia \\ ${ }^{2}$ Fakultas Ilmu Budaya, Universitas Sebelas Maret, Jl. Ir. Sutami 36 A Surakarta, Indonesia
}

\begin{abstract}
Batik is one of Indonesia identity. Batik also becomes macro and micro identity. Micro identity means local identity. One of micro identity is Sangiran batik. Sangiran batik rises as new identity of Sragen regency called Parang Sukawati. This research is about local identity around parang sukowati batik. Parang Sukawati batik has uniques. It try to rise local identity and leave the basic pattern of Surakarta batik. It try brings Sangiran sites in the batik because Sangiran is as world heritage and called Sangiran Doom. This heritage is in the culture area of Sangiran. Sangiran is old sites that recognized by UNESCO as world culture heritage. Thee is found many fossils and the important thing is the human fossil called pitegantropus erectus. While batik is also recognized as Unesco's world cultural heritage. Batik is a cultural heritage from Indonesia. These two things are used as media to bring out local cultural identity into Sangiran batik. Sangiran Batik is a batik with a motif originating from Sangiran as an ancient site. Sangiran is where the oldest ancient humans were found in the world. The Sragen people regard Sangiran as one of their global local characteristics. This expression was delivered in the form of batik artwork. So, comes the Sangiran typical batik motifs in the form of ancient human images, fossils, and other typical flora and fauna of batik. The meeting between batik and Sangiran site is inseparable from the sociocultural situation of the community. Around the site, there are areas of batik craft so that the Sangiran site provides inspiration to create a design with the theme "Sangiran batik". Sangiran Batik is then used as a medium to express identity. The manifestations of these inspirations are in the old ivories, parang motif, and flora and fauna from Sragen regency.
\end{abstract}

Keywords: parang sukowati, Sangiran, batik motif

\section{Introduction}

Basically, batik is a work of cultural tradition that is admired by the nations of the world long before batik was appointed by UNESCO as world cultural heritage. In its development, batik as a valuable work of the Indonesian people is inseparable from various influences, both from outside cultures and environmental influences. Changes in the times and environment are indisputable and cannot be separated from the process of the development of batik at any time, so that the influence triggers the presence of batik in harmony with its development (Dullah, 2002: 7). The wide variety of forms and patterns of batik that are integrated with the techniques of making them and reflect the background of tradition and the contents of cultural aspirations make batik an identity of cultural heritage. This is what makes batik not always beautiful, but merges with moral and customary rules.

A piece of batik cloth made through a process of research, dyeing and pelorodan makes it a traditional literature. Batik technique is an original skill possessed by the ancestors of the Indonesian people since centuries ago. Batik activities, especially in Java, have grown and 
developed and have produced diverse types and types of ornamentation that are rich in color. Although there are differences between Yogya and Solo batik and coastal batik, it shows that Indonesian batik is rich in various styles. Similarly, batik that develops around Soloraya has their own characteristics, because it is motivated by their environment. One of them is the batik style that developed in the Sragen area, especially those around the Sangiran site in the form of a museum.

At present the museum is understood as a place for storing, caring, securing and evidence of artifacts of human culture, nature and its environment. This is intended as an effort to support the protection and preservation of the nation's cultural wealth. In the new paradigm, museums are also seen as a forum where debates and controversies occur regarding the material and content presented. With the existence of the museum, it is very easy for someone to study and observe historical relics in the past. Ancient museums such as the Sangiran Archaeological Museum in Sragen Regency can be an effective tool in helping the process of changing times.

As one of the museums listed in UNESCO's world heritage, the ancient Sangiran museum has the potential to be developed. Various attempts were made by the local government and surrounding communities to introduce this potential through conservation and promotion. This is related to the imaging of the City of Sragen which has the power to form a brand of its identity. Sragen is one of the regency cities in Soloraya which launched its tagline city branding as The Land of Java Man, tying its flagship tourism potential to the Sangiran museum. In the industrial sector, the Sragen area combines industrial zones in the form of small and medium batik business units.

Based on this fact, it has raised issues that need to be studied to reveal the potential of the area in finding the identity and image of Sragen Regency. Among these are the basis for choosing the potential of Sangiran batik as the city's imaging identity. The extent to which the Sragen local government has developed the Sangiran batik craft and the efforts it has developed. Therefore it is necessary to know about people's perceptions of the development of Sangiran batik as part of the search for the identity of the Sragen city.

\section{Batik at a Glance}

Batik is one of the cultural objects that has philosophical and symbolic values typical of the archipelago. In its development, batik experienced a journey from time to time in the process, technical and motifs in various regions. Therefore batik develops with an artistic basic view which is based on the local cultural background according to the demands of the times. In the context of tradition, batik has a complete understanding that can not be separated between the motifs and processes related to fine work and beauty.

The process of batik requires carefulness and patience in controlling themselves and concentration and a relatively long time depending on the style and color you want. Batik, in addition to aesthetic wear objects, also has a spiritual dimension that shows a high level of culture. It has long been rooted in Indonesian culture, and can highlight the unique characteristics of Indonesia (Koentjaraningrat, 1985: 16).

Batik fabric whose motives are made by using a writing stick or stamp and wax (wax) as a color barrier have manifested various types. Batik technique is an original skill possessed by the Indonesian people since centuries ago. Batik activities especially in Java grow very fertile and produce two types of patterns. The distinction between Solo and Yogya batik types and the types of batik in the north coast of Java shows that Indonesian batik has a variety of patterns. Both types of batik are determined by their cultural and environmental background, 
so they have their own characteristics. In its development, various types of batik were born with a background to the local environment.

Based on its history, batik is a method of decorating on a fabric surface known as the Surface design. The process of batik begins with the depiction of motifs through the application of wax (wax) using a writing canting or stamp. Then do the dyeing with natural dyes in accordance with the desired color, ending with the pelorodan process. The end of this process is the removal of wax (wax) on the fabric, after which the motifs and colors emerge. In the past, printed batik was not seen as batik in the true sense and was limited to written batik. But this time has changed, although batik was originally present solely on the basis of commercial considerations, even lately known as a kind of batik-patterned fabric called "batik printing" with the printing process.

At the end of the 20th century, the use of traditional batik seemed to decrease. Batik is seen more as a color obstacle technique that has advantages in the visual aspect compared to the tie dye technique. Actualization of modern batik is when we are able to learn the historical background, philosophy, symbols, techniques, expressions and all aspects of its creation. Today we are confronted with the phenomenon of written and stamped batik pressed by other types of textiles, since 1970, batik began to be displaced as a fashion material, then developed into other functions such as as a complement to the interior or household and souvenirs. The wide variety of standards is modified with a variety of new motifs that are freer in color.

In batik there are various creative or innovative possibilities which include raw materials of fabrics, dyes, processes and techniques, improvements to the development of functions. It is natural that batik has a commercial dimension and innovation, namely through side effects and diversification of batik products with various needs and interests. Its development towards the use of the present has entered the realm of collaboration with science and technology by producing new products. Various parties have tried to explore batik which can be applied and utilized to enrich the diversity of Indonesian batik. Its development will broaden the scope of acceleration in the world of batik. With the expansion of the field of use of batik also has opened new opportunities in the user community. One of them is batik as an expression of promoting the Sangiran museum site in Sragen, Surakarta.

\section{Batik As Expression and Creativity Media}

As a material product, batik culture is an inherent part of national culture and is the identity of the Indonesian people. Batik has grown and developed in various dimensions through the passage of space and time to meet the needs of the community. Nowadays batik is in the spirit of the times, that is when creativity becomes a dominant factor in the midst of the various challenges and obstacles that prevent it. The relationship between creativity and source of ideas that gave birth to the phenomenon of a creative expression, as a concept that departs from the use of environmental assets. In the present condition, it is not only a question of its existence but also of the order and repositioning of batik in its various dimensions. Batik is not just a cultural object but also as a means to convey messages from the identity of a community.

Based on its history, Keraton Solo and Yogya batik called Vorsenlanden batik has shown this with strict standards in its use (Djoemana, 1990: 8). Along with the development and changing times, environmental influences have motivated creativity in the creation of batik today. Then there are Batik Saudagaran and Batik Petani patterns that develop outside the palace, in the form of prohibited patterns with a combination of entrepreneurial tastes and community aspirations. In its development emerged batik style that involved outside 
influences such as the Netherlands, China, and India. Some batik works are known as 'three countries' and together with the discovery of canting tools and synthetic dyes around 1850 the early development of coastal batik in the archipelago.

The development of the phenomenon of creativity in batik later influenced by various factors resulted in the diversity of batik in Indonesia. The creativity of batik on batik continues in free-form Coastal Batik works and expression media with decorative meanings different from the Kraton Batik which is philosophical. An important stage in creativity as a medium of expression is increasingly open in the era of independence, when the government encouraged the creation of Indonesian Batik. The "this" category emerged based on the spirit of unity and the formation of national identity, no longer from the ego of the batik-producing region. Even so the characteristics of the batik area remain still known and visible in the elements of its style. The spirit of creativity in batik goes slowly but surely the diversity is increasingly diverse, while removing the stigma that batik is typically Javanese (Anas, 2011: 80) ..

Nowadays batik has become a commodity in the sphere of the creative economy that cannot be separated from the control of market demand. This is indicated by the presence of Coastal Batik, Batik Saudagaran, Dutch Batik, Chinese Batik and so on. Batik is a commodity and a commodity, and an identity that leaves behind the monumental peaks of past creativity. This symptom continues when the dynamics of batik economy in the future play a central role in the rise of batik in Indonesia. Batik is no longer just a "Javanese" product, but has become a cross-ethnic cultural instrument with the application of batik as a formal dress since 1970. Since then it has actually been pioneered into industry and economic power. Thus batik has shown its strength in the aspects of creativity and economics as well as a medium of expression of local identity.

\section{Local Identity on Parangsukawati Batik}

Sangiran then Sangiran is an archeological site (ancient human site) in Central Java, which is located north of Solo City about $15 \mathrm{KM}$ precisely in the Krikilan Village, Kalijambe District, Sragen Regency. The Sangiran site gate is on the Solo-Purwodadi highway near the border between Gemolong and Kalioso (Karanganyar Regency). This gate is used as a sign to the Sangiran Site in the Krikilan Village in two districts and four sub-districts. The location of this site is in Sragen Regency which covers parts of Gemolong, Kalijambe, and Plupuh Districts and Karanganyar Regency which covers parts of Gondang Rejo District. Sangiran is the most important ancient human site in Indonesia, even leading in the world because it is one of the few Hominid sites in the world.

In 1996 the Sangiran Site was designated a World Heritage by UNESCO under the name Sangiran The Early Man Site. This determination is based on ICOMOS recommendations which have reviewed and learned the truth of the potential of Sangiran Site which has values as cultural heritage. Sangiran Site is one of the Key sites for understanding human evolution through human and animal fossils. This site describes the evolution of homosapien from the time of the Plestocene to the present. After being designated as a world cultural heritage, the government has the consequence of carrying out regular management. One of them is maintaining and developing universal values that are attached to Sangiran Site.

Generally the people around Sangiran Site still characterize rural communities with a simple life. They are very friendly, helping each other and still close to the tradition of mutual cooperation (Local genius). Their residential buildings are walled with wood or woven bamboo, a pyramid-shaped roof and ridges of zinc, often decorated with figures of wayang figures. In addition to his daily activities as a farmer, some people around Sangiran Site also 
carry out craft activities. The various handicraft products include souvenirs made from stone which are typical in Sangiran. In addition, what developed later was the manufacture of batik and handicrafts and coconut shells. Batik is considered a handicraft that has high artistic value and beauty, and has been a part of Indonesian culture, especially Java, for a long time (Rizali, 2013: 7).

In its development, patterned batik was used as a city imaging identity based on the main icon of Sragen Regency. The city has the potential of the tourism sector which is the mainstay of Sangiran Ancient Human Site which holds an interesting mystery to be revealed. In 2012 the Sragen Batik Design competition was held, this was a new breakthrough about Sangiran as its icon. In the competition, the depiction of motifs is dominated by the evolutionary patterns of early human development that illustrate the existence of Sangiran. Batik as a cultural heritage is one way to awaken the nation's culture by giving birth to local identity and environmental potential that has a community around Sangiran. In this case, Sangiran Batik is a batik work with the identity of the special motifs of the Sragen region, which contributes to the treasury of Indonesian assets in the development of Science.

The existence of regional government support before 2016 for batik designs full of local symbols implemented in the attire of elementary schools, junior high schools and senior high schools. In addition, it is also used as the identity of all ranks of Civil Servants in Sragen Regency, as an effort to explore and recognize the potential of the city of Sragen. This is not only special for the local area, but also the introduction of promotion for the world, especially in the development of archeology, geology, paleometropology and biology. This condition has taken place since the establishment of the Sangiran Site as a World Heritage area by UNESCO and has been very much considered in its development.

According to the textile design theory there are two important elements in its appearance, namely the motifs and colors which are characteristic as well as symbols of their local identity. To find out the existence, it can be explained the motives and colors that have philosophical and symbolic meaning as follows;

1) Sangiran Batik Motif

- The Motive of Human Evolution, describes the form of human figures who are undergoing development or evolution (Charles-Darwin's theory) which according to Islamic understanding has fallen. This motif is a sign that Sangiran batik has a symbol where traces of ancient humans were found. Because of that, since the beginning of 2017, it has not been used anymore.

- Gading Carved Ivory Motif, is one of the findings of ancient stegodon or elephant fossils representing artifacts in Sangiran. Even though the elephant is not depicted as a whole, the carved ivory becomes a symbol on the Sangiran batik.

- $\quad \square$ The motif of Dewi Sri, the figure of Dewi Sri is believed to be the Goddess of Fertility according to Javanese mythology. The shape is combined with yellowing rice plants and scattered grains of rice as happened at harvest time.

\section{2) Sangiran Batik Color}

The various color compositions on Sangiran batik have philosophical and symbolic meaning in bright tones. Some of these colors include green which means fertility. In addition there is brown as the color of the soil which means fertility, and red as a symbol of grandeur. Sangiran batik cloth was then applied in school uniforms for various levels of students and civil servants in Sragen Regency during the 2012-2016 regional administration. The uniforms are worn on study days with different types of models and colors at each level, whereas for civil servants worn on certain days and on flag ceremonies, although not all fabrics are made through the process of batik, but also done by printing techniques. The Regional Government's 
policy in developing tourism potential and Sangiran batik as an image of the city of Sragen. It is intended to foster a sense of pride and realize to the public that the concept of batik design that has a historical philosophy can be an icon of identity depiction. Thus Sangiran batik has become a medium of communication and local identity in Sragen Regency.

Sangiran Batik has become a phenomenon that develops according to the times, changing from time to time. There is an effort made by the Sragen Regency Government to display its identity as an industrial and tourism city. Since 1996 when the Sangirand site was designated as a world heritage by UNESCO, it has been known in parts of dubia. In addition to having a Sangiran site, the city of Sragen has long developed a furniture and batik industry, which later became a supplier of batik products in Solo. In searching for their identities, batik entrepreneurs and artisans in Masaran and Plupuh districts have always produced classic batik sourced from the Keraton Surakarta batik. The batik artists try to develop their creativity by creating innovative new ideas. With the aim of finding Sragen's local identity as an icon on Bumi Sukowati.

Since the beginning of 2017 after going through the exploration process, the results of the Sangiran batik incarnation have become what is called "Parang Sukowati" batik. Philosophically, the design of this batik originates from the idea of a blend of the traditional motifs of the Keraton Surakarta bati with decorative abstraction motifs. The hallmark of the Sangiran site and the Sragen icon. The combination of these results in harmonization of a batik work that is easily known. Some of the icons contained in the batik 'Parang Sukowati' as the development or change of Sangiran batik include:

Luk-lukan Parang Modern (the development of parang motifs on the classic batik of the Keraton Surakarta) illustrates the dynamic life of the Sragen people.

- The Ancient Elephant ivory gate is the entrance gate of Sragen Regency, which is a historical and archaeological tourism in the Sangiran area.

- Pendopo is the central government of Sragen Regency.

- Plants that depict flora and nature as typical icons of Sragen Regency in black.

- Branjangan Bird illustrates one of the fauna icons in the Sragen area.

- Batik people who describe Sragen Regency which is one of the batik industries, especially those in the Kliwonan area.

- Basic fresh or brown colors represent the fertile farmlands of Sragen. (source; Catalog of Sukowati Museum, Sragen Regency 2017).

Parang Sukowati Batik is a development of Sragen's local identity in the form of a harmonious blend of elements of the Surakarta Keraton cultural tradition and the potential of the Sragen region, while changing the comprehensive impression of Sangiran batik. The development of a regional product related to its local identity is inseparable from the policy of the governing regional head official. The development of Parang Sukowati batik in Sragen Regency is an effort of the regional government in the context of searching for its local identity. Starting with the existence of the Sangiran batik which only illustrates the elements of the Sangiran Museum site which was later developed into the Parang Sukowati batik, it was a model for developing batik as a tradition of Indonesian culture.

\section{Conclussion}

Since the 2012 batik competition has been made with a creative approach, as well as responding to the aspirations and changing times. Batik has also developed in the diversification of certain forms and functions in modern society. As a material cultural object, batik is an inherent part of national culture and is the identity of the Indonesian people. Batik 
has grown and developed in various dimensions through space and time trajectories in people's lives, both in the field of function and other socio-cultural needs. Since its enactment by UNESCO, batik has become a world heritage as a work of native geniuses of the archipelago. These conditions helped raise back and stretching batik in various regions, including in the Sragen regency, Central Java.

The creative process in imaging batik is not just decorating a piece of cloth, but also as a container of life values and beliefs. In its development until the fabric has been born a variety of patterns, ranging from traditional motifs to the creation of modern batik (new creations). its presence is caused by various factors and needs. Consumers who continue to develop, as well as the development of communication technology as a more effective and efficient expression medium, the concept of imaging the Sragen Regency city with the slogan The Land of Java Man reminds one of its superior potential, namely the Sangiran Museum through the development of batik motifs. Sangiran Ancient Man Site and then also developed Gading Gajah Primera which has become an icon in the field of tourism by processing Sangiran batik motifs now become Parang Sukowati Batik as a symbolic and meaningful identity.

To disseminate the meaning of city imaging for the people of Sragen Regency, socialization should be carried out, especially for its users. The perception of the community towards the influence of Sangiran tourism potential and its batik has not yet been fully realized. By repacking the motifs taken from the Sangiran Site icon continuously producing regional batik products that can become one of the local cultural imagery, as well as the identity of Sragen Regency. In matters related to the theory of Human Evolution by Charles Darwin, the Sragen Regional Government reviewed it, considering that the image that was built from the basic idea of human early creation was no longer relevant. Therefore, since the beginning of 2017 there has been a change in the identity of Sragen Regency by adopting Batik Parang Sukowati as its icon.

\section{Acknowledge}

Thank you to the Postgraduate Research Scheme, PNBP Universitas Sebelas Maret for funding this research

\section{REFERENCES}

1. Doellah, H. Santosa, 2002, The Impact of time and Enviroment, Surakarta: Danarhadi

2. Balai Pelestarian Situs Manusia Purba Sangiran, 2010, “Undang-undang No. 10, Tahun 2010 tentang Cagar Budaya".

3. Djoemana, Nian. S, 1990, Ungkapan Sehelai Batik, Jakarta: Djambatan

4. Koentjaraningrat, 1985, Kebudayaan Mentalitas dan Pembangunan, Jakarta: PT. Gramedia.

5. Anas, Biranul Zaman 2011, "Batik-Kretifitas-Ekonomi” Menggapai peran Batik dalam Ekonomi Kreatif, makalah dalam World Batik Summit 2011, Jakarta 28 September 2011.

6. Rizali, Nanang, 2013, Nafas Islami dalam Batik Nusantara, Surakarta: UNS Press

7. Katalog Museum Sukowati dan Dinas Perindusterian Perdagangan Kabupaten Sragen, Tahun 2017

8. Sunarya, YanYan, 2014, Batik; Digitalisasi Kreatif Motif dalam gaya Desain Dunia, Bandung: Penerbit ITB 
1. Doellah, H. Santosa, 2002, The Impact of time and Enviroment, Surakarta: Danarhadi

2. Balai Pelestarian Situs Manusia Purba Sangiran, 2010, “Undang-undang No. 10, Tahun 2010 tentang Cagar Budaya".

3. Djoemana, Nian. S, 1990, Ungkapan Sehelai Batik, Jakarta: Djambatan

4. Koentjaraningrat, 1985, Kebudayaan Mentalitas dan Pembangunan, Jakarta: PT. Gramedia.

5. Anas, Biranul Zaman 2011, "Batik-Kretifitas-Ekonomi” Menggapai peran Batik dalam Ekonomi Kreatif, makalah dalam World Batik Summit 2011, Jakarta 28 September 2011.

6. Rizali, Nanang, 2013, Nafas Islami dalam Batik Nusantara, Surakarta: UNS Press

7. Katalog Museum Sukowati dan Dinas Perindusterian Perdagangan Kabupaten Sragen, Tahun 2017

8. Sunarya, YanYan, 2014, Batik; Digitalisasi Kreatif Motif dalam gaya Desain Dunia, Bandung:

9. Penerbit ITB 